Volume 14

Issue 2. Growing Roots of Indigenous Wellbeing

Article 5

Full Issue DOI: 10.32799/ijih.v14i2.32958

October 2019

\title{
Colonial Trauma: Complex, continuous, collective, cumulative and compounding effects on the health of Indigenous peoples in Canada and beyond
}

Terry Mitchell, Professor

Balsillie School of International Affairs, Laurier University, Waterloo, Ontario, Canada, N2L 6C2

tmitchell@,wlu.ca

Courtney Arseneau, Ph.D. Candidate

Affiliation: Laurier University, Waterloo, Ontario, N2L 3C5

carseneau@,wlu.ca

Darren Thomas, Lecturer

Affiliation: Laurier University, Brantford, Ontario, N3T 2W2

dthomas@,wlu.ca

Follow the International Journal of Indigenous Health at:

https://jps.library.utoronto.ca/index.php/ijih/index

\section{Recommended Citation}

Mitchell, T.; Arseneau, C.; \& Thomas, D. (2019). Colonial Trauma: Complex, continuous, collective, cumulative and compounding effects on the health of Indigenous peoples in Canada and beyond.

International Journal of Indigenous Health, 14(2), 74 - 94. DOI 10.32799/ijih.v14i2.32251 


\title{
Colonial Trauma: Complex, continuous, collective, cumulative and compounding effects on the health of Indigenous peoples in Canada and beyond
}

\begin{abstract}
Indigenous peoples across the globe suffer a disproportionate burden of both mental and physical illness relative to Settler populations. A substantial body of research indicates that colonialism and its associated processes are important determinants of Indigenous peoples' health. In Canada, despite an abundance of health research documenting inequalities in morbidity and mortality rates for Indigenous peoples, relatively little research has focused on the political, historical, cultural basis of health disparities. This paper advances a theory of colonial trauma as a conceptual framework with which to understand Indigenous health and mental health disparities. Colonial Trauma is described as a complex, continuous, collective, cumulative and compounding interaction of impacts related to the imposition of colonial policies and practices which continue to separate Indigenous Peoples from their land, languages, cultural practices, and one another. The theory of colonial trauma is presented as useful a framework for understanding the links between persistent health disparities, the traumagenic nature of colonialism and the right of self-determination.
\end{abstract}

\section{Keywords}

Canada; Colonialism; Indigenous peoples; Trauma; Colonial Trauma; Health disparities; Determinants of health

\section{Creative Commons License} (C) $(\Theta \Theta$

This work is licensed under a Creative Commons Attribution-Noncommercial-No Derivative Works 4.0 License. 


\section{Introduction}

Colonization has been linked to adverse Indigenous health outcomes, such as higher rates of infant mortality, a greater burden of disease, and reduced life expectancy in Canada and internationally (Smylie \& Firestone, 2016). The long-term impact of colonialism is, however, an under-examined aspect of Indigenous health in need of further research. A recent review of mental health literature consisting of 223 articles from eleven data bases and two Indigenous health-focused journals demonstrates that mental health research related to Indigenous peoples in Canada overemphasizes suicide and problematic substance use and that while the literature demonstrates a consistent reference to colonialism a "more critical use of the concepts of colonialism and historical trauma is required." (Nelson \& Wilson, 2017, p.93). While there is considerable reference to the impact of colonialism there is little to no explicit reference to colonial trauma.

Colonial trauma is a critical health issue posing a global health challenge for the world's 370 million Indigenous peoples. Indigenous populations across the globe suffer a disproportionate burden of mental and physical illness (Doyle, 2012; Kirmayer \& Valaskakis, 2009; Kral et al., 2011; Marrone, 2007; Waldram et al., 2006). The significantly higher incidence of a variety of physical and mental health conditions among Indigenous populations persists within both underdeveloped and developed countries (United Nations, 2009). In a review of the mental health of the world's Indigenous populations Cohen (1999) wrote of the contemporary form of corporate colonialism and the threat to place-based peoples linking Indigenous Peoples relationship with land and the disruption of their life way to their health:

Indigenous peoples continue to be seen as standing in the way of development because they do not want to relinquish their lands for exploitation, and while they are no longer subjected to the brutal methods of slaughter and dislocation that were employed in the past, they are still subject to forces used with the intent to remove them from the land and destroy their way of life. (p. 7).

The displacement of Indigenous peoples within Canada from their traditional land bases and the severance of their cultural connections from the land and traditional lifeways has resulted in social, cultural, spiritual, emotional and physical disruptions causing profound social and health impacts related to cultural losses, alienation and identity disruption (Kirmayer, Brass, \& Tait, 2000; Maxim, White, Beavon, \& Whitehead, 2001; McCabe, 2007; Miller, 2004; Mitchell, \& Maracle, 2005; Morrissette, 1994; Nelson \& Wilson, 2017; Waldram, 1997). Former United Nations Special Rapporteur on the Rights of Indigenous Peoples, James Anaya, described the contemporary situation of Indigenous peoples in Canada as a crisis where Indigenous communities live in situations comparable to third world conditions (Anaya, 2014). 
Despite persistent health disparities and well documented cultural disruption, there continues to be a dearth of scholarship on the health needs of Indigenous populations (Young, 2003) and the reasons for the gross health disparities between Settler populations and Indigenous populations. Health needs, risk factors, and Indigenous health disparities research need to be conducted within the socio-political context of Indigenous peoples' lives to avoid an individualistic, pathologizing, and victim blaming perspective (Loppie Reading \& Wien, 2009; Nelson \& Wilson, 2017).

\section{The Colonial Context of Contemporary Indigenous Health Disparities}

The most common factor uniting the world's 370 million Indigenous peoples (World Health Organization, 2007) beyond their cosmovisions and identities as land-based peoples is their shared experience of colonialism (Nelson \& Wilson, 2017). While there is a tremendously rich diversity among and across Indigenous peoples around the world characterized by distinct histories, languages, cultures, and social organization, Indigenous peoples share a deep connectedness to their land and the traumatic losses of traditional territories (Cohen, 1999). Canadian Indigenous scholar Simpson (2004) articulates the importance of land and the contemporary forms of colonialization expressed in extractivism.

Our knowledge comes from the land, and the destruction of the environment is a colonial manifestation and a direct attack on Indigenous knowledge and Indigenous nationhood ... In present times environmental destruction of Indigenous territories facilitated by state governments and instituted by large multinational corporations continues to remove Indigenous peoples from the land and prevent Indigenous peoples from living our knowledge. (p. 377)

The complex relationship between Indigenous peoples and the land is a profoundly significant one related to cultural survival, economic and environmental sustainability, communal and individual identity, and spiritual and physical health (Duran, 2006; Fry \& Mitchell, 2016; Laduke, 1999; RCAP, 1996; Stewart, Riecken, Scott, Tanaka \& Riecken, 2008).

Indigenous collectives have a profound relationship to the earth in which the integrity of their territorial lands and their relationship cannot be compromised without significant social, cultural, and spiritual impact (Frye \& Mitchell, 2016). It is essential, therefore, to appreciate Indigenous Peoples' need to sustain traditional teachings and practices and to consider the colonial traumagenic impact of further disconnection from the land (Arquette et al., 2002).

\section{Contemporary Colonialism}

Colonialism has been defined as "the takeover of territory, appropriation of material resources, exploitation of labour and interference with political and cultural structures of another territory or 
nation" (Loomba, 2005, p. 11). Colonialism has also been defined by practices of cultural genocide, the spread of deadly diseases, the banning of Indigenous languages, forced assimilation and the illegalization of social, cultural and spiritual practices (Paradies, 2016). Colonialism has been identified as "a cause of mental illness linking residential school experiences with suicidal ideation or attempts" (Nelson \& Wilson, 2017, p. 94). Contemporary forms of colonial relations exist in which, far from living in a post-colonial era, Indigenous peoples have become primary targets of active displacement and assimilation through the workings of extractive industries (Choudry, 2010; McClintock, 1992).

In contributing to a theory of colonial trauma as a basis for why Indigenous peoples globally experience gross health disparities as compared to Settler populations in both developing and wealthy nations we advance a theory of colonial trauma which involves (a) the colonial traumagenic agent; (b) the distress in response to the traumagenic event and related losses; and (c) social responses to both the traumagenic events and the traumatic distress.

\section{The Canadian Context}

The colonial relationship between the Europeans that came to North America, the early Newcomers and Settlers that followed, and the people who are Indigenous to the land, has been marred by gross cultural misunderstandings, pervasive racism, successive waves of disease, land control, and aggressive assimilation policies focused on dismantling Indigenous families and communities through the infamous Indian residential and boarding schools in Canada (Adams, 1989; Berger, 1991; Cardinal, 1969; Miller, 1991; York, 1990).

It is believed that there were over 2 million First Nations before the arrival of Giovanni Caboto, an Italian explorer sailing under British flag, in search of the riches of Asia, who landed on the east coast of Canada in 1497. First contact with the Beothuks forecasted the dire future of Indigenous/Newcomers relations. The Beothuks of Newfoundland, who initially kept to themselves, were ultimately eliminated; killed off entirely by disease, starvation and the Newcomer's bullet (Miller, 1991). The Beothuks were the canary in the coal mine, foretelling the potential danger of the incoming Newcomers and their ultimate betrayal.

Indigenous Peoples in what is now known as Canada largely welcomed the British and the French, the Newcomers who were greatly dependent upon Indigenous peoples when they arrived on the new continent. Out of this early dependency of the Newcomers developed productive, mutually beneficial relationships through trade and marriage. These Indigenous communities did not surrender their lands to the foreigners, rather treaties, considered as international agreements, were signed between 'Nations' (Waldram, Herring, \& Young, 2006, p.13). The British Crown established a relationship with First Nations that acknowledged their sovereignty in the Royal Proclamation of 1763, indicating land 
title recognizable by British law. The powers of the federal government through the Department of Indian Affairs (DIA) were however far reaching and violated the spirit and intent of the Royal Proclamation. By 1880 the DIA had drafted policies of assimilation described by Miller (2004) as

a wide-ranging ideology and policy that seeks to eradicate a people's identity and cultural practices in favor of another group's way of doing things. Sometimes referred to as cultural replacement, assimilation contains two major thrusts or emphases. First the assimilation aims to stamp out those aspects of the target group's attitudes and practices that are viewed as objectionable, and second, the proponent of change seeks to implant its outlooks and customs. (p. 225)

The Indian residential schools first established in 1883 with involuntary attendance were a powerful and tremendously enduring traumagenic expression of the Canadian state's assimilation policies. In the years that followed, important spiritual and cultural ceremonies were banned, such as the Potlatches in 1884 and the Sun Dance in 1886. The First Nations were "legally infantilized and politically patronized" (Miller, 2001, p. 102) and their cultures, communities, families, and selves battered by an unrelenting "vicious assimilative assault" (p. 251). The residential schools arose from a devastating assimilative policy with estimations that as many as $24 \%$ of all of the children died while at the schools (Waldram, Herring \& Young, 2006).

On the occasion of Canada's celebration of the first one hundred years of confederation Chief Dan George (1967) spoke in Vancouver of his experience of colonial relationships in Canada. His talk has been reprinted in an anthology of Native poetry in Canada, by Armstrong \& Grauer, 2001)

How long have I known you, Oh Canada? A hundred years? Yes, a hundred years. And today, when you celebrate your hundred years, Oh Canada, I am sad for all the Indian people throughout the land... In the long hundred years since the white man came, I have seen my freedom disappear like the salmon going mysteriously out to sea. The white man's strange customs, which I could not understand, pressed down upon me until I could no longer breathe. (p.2)

A Royal Commission on Aboriginal Peoples (RCAP) was conducted between 1991 and 1996 which resulted in the Canadian government closing its last Indian residential school. In June 2008, the Prime Minister of Canada, Stephen Harper, spoke of Indigenous and Settler relations and the role of Canadian administration in harming Indigenous cultures and peoples in his apology for the federal government's residential school policy (Indian and Northern Affairs Canada, 2008). The text of the Canadian apology describes the assimilative objectives of the residential school system based on the racist assumptions of inferiority. The text goes on to confirm that the children were "inadequately fed, 
clothed and housed. All were deprived of the care and nurturing of their parents, grandparents and communities and some children died there and others never returned home". Prime Minister Harper (2008) continued to talk about the devastating collective impact on culture linking residential schooling to the origin of contemporary social problems.

... The government now recognizes that the consequences of the Indian residential schools policy were profoundly negative and that this policy has had a lasting and damaging impact on aboriginal culture, heritage and language...The legacy of Indian residential schools has contributed to social problems that continue to exist in many communities today... We now recognize that it was wrong to separate children from rich and vibrant cultures and traditions, that it created a void in many lives and communities, and we apologize for having done this.... (https://www.cbc.ca/news/canada/prime-minister-stephen-harper-s-statement-ofapology-1.734250)

\section{Post-Traumatic Stress Response to Colonial Traumagenic Forces}

These colonial injuries persisted over two centuries and are still present today in new and unacceptable forms of colonialism exemplified by child welfare practices, inordinate rates of imprisonment, and the land violations of extractive industries. The collective impact of the enduring colonial trauma can be understood within the larger health framework of post-traumatic stress disorder (PTSD). PTSD affects individuals in a vicious cycle of denial, avoidance, and becoming overwhelmed with memories and related feelings. Post-traumatic stress is unique as a mental health diagnosis and appropriate for framing an understanding of the Indigenous collective and intergenerational trauma because a diagnosis is dependent upon exposure to a traumatic event. PTSD results from externally imposed trauma which provides a social-historical context for examining colonial trauma and the impacts of which have too often been viewed as behaviours or conditions rooted in individual character flaws or cultural deficits.

The alternate term post-traumatic stress response (PTSR) as posited by Mitchell and Maracle (2005) is a more appropriate model for understanding and addressing colonial trauma. The PTSR model reframes PTSD symptoms as human responses to extreme circumstances, clearly identified as a response to an external trauma that is outside the range of tolerable human experiences. Indigenous peoples cannot be expected to be resilient to simply 'bounce back' from traumatic stress in the face of ongoing colonial traumagenic forces (Thomas, Mitchell \& Arseneau, 2016). Responses to pervasive colonial trauma have manifested in the form of chronic diseases, poverty, and high rates of youth suicide, among other health disparities and social inequalities (Loppie Reading \& Wien, 2009). These various expressions of colonial trauma experienced by Indigenous individuals and collectives illustrate how the 
post-traumatic stress results from, and is a response to, the traumagenic events and traumagenic centuries of Settler colonial imposition. In the sections that follow, we will describe colonial trauma as having complex, continuous, collective, cumulative and compounding effects on the health and wellbeing of Indigenous communities.

\section{Conceptualizing Colonial Trauma}

Trauma arising from the direct and indirect impacts of colonization have been discussed within the literature as a negative determinant of Indigenous health (Smylie \& Firestone, 2016). There are many terms used to characterize the enduring trauma of Indigenous peoples; historical trauma (Brave Heart, 1993, 1999); collective trauma (Abadian, 1999; Evans-Campbell, 2008; Krieg 2009); post-traumatic stress (Manson et al. (Eds.), 1996; Prussing, 2014); intergenerational trauma (Braveheart \& Debruyn, 1998; Evans-Campbell, 2008; Funston, 2013; Sherwood, 2009; Sweet et al., 2014); Native Holocaust (Stannard, 1992); historical loss (Whitbeck et al., 2004); post-traumatic stress response (Mitchell \& Maracle, 2005); soul wound (Duran, 2006); colonial trauma (Evans-Campbell, 2008) and colonial injury (Kirmayer et al, 2014).

Evans-Campbell (2008) discusses the limitations of the post-traumatic stress disorder (PTSD) model in understanding the impacts of trauma over multiple generations. She suggests that PTSD does not adequately account for the intergenerational transmission of trauma and the relationship between historical and contemporary trauma responses. Instead, she calls for a shift towards the concept of historical trauma. Historical trauma captures the collective trauma of cultural groups that can continue across generations (Crawford, 2014) further described by Mitchell \& Maracle (2005).

Historical trauma is referred to as collective emotional and psychological injury over the lifespan and across generations. It is viewed as resulting from a history of genocide with the effects being psychological, behavioural, and medical. Historical trauma response has been identified as a group of reactions to multigenerational, collective, historical wounding of the mind, emotions, and spirit. Historical trauma for Aboriginal populations is understood to be linked directly to the banning of cultural practices, policies and institutions of assimilation, and loss of culture. (p. 15)

However, use of the term historical trauma may be misinterpreted as an artifact of the past rather than an ongoing concern, potentially marginalizing and minimizing the phenomenon of intergenerational trauma suffered by Indigenous peoples (Mitchell \& Maracle, 2005). A review of the literature indicates that a failure to link intergenerational and historical trauma to the colonial agent may serve to 
"individualize and pathologize the impacts of colonialism which is at its heart a collective and structural force, requiring collective and structural change" (Nelson \& Wilson, 2017, p. 102).

\section{Colonial Trauma}

Raymond Quock, a Yukon Tlingit/Talhtan man, once said "You don't come with guns anymore; you come with briefcases and we kill ourselves" (Mitchell, 1993, p.257). This haunting phrase reveals the perverse power of colonialism and the pervasive impact of internalized oppression. The term colonial trauma denotes both the political nature and collective impact of the trauma that Indigenous communities endure. We advance the use of the term colonial trauma as this term more identifies the external and political origin of the trauma embedded in both historical and contemporary colonial relations.

There is a conspicuous dearth of scholarship that seeks to define and operationalize colonial trauma in all its complexity and to consider the impacts not only on the social but also physical and mental health of a population. The early definition by Evans-Campbell (2008) described colonial trauma as an active process of political aggression involving "both historical and contemporary events that reflect colonial practices to colonize, subjugate, and perpetrate ethnocide and genocide" (p.335). This understanding of colonial trauma recognizes that the psychological, social, and cultural impacts of colonialism extend far beyond the level of the individual to the collective. The concept of colonial trauma presents the persistent, systemic intrusions of colonization as responsible for the oppression of an entire cultural group (Lloyd, 2000) and the related social and health disparities at the population-level.

\section{The Colonial Traumagenic Agent}

The concept of colonial trauma can be utilized to frame the accountability of governing nations, as it points to the political source of the trauma while referring to a collective versus an individual target. Colonial trauma reflects the systematic and institutionalized violence that continues to be legitimized by policy, law, and political interference (Mitchell, 2016). Colonial traumagenic forces have contributed to the psychological, social, and physical health crises faced by Indigenous communities globally (Mitchel \& Maracle, 2005; Mitchell \& MacLeod, 2014). Colonial trauma is, therefore, an appropriate term to describe a traumatic era of over five centuries of political assaults against Indigenous peoples

(Whitbeck, Adams, Hoyt, \& Chen, 2004). This enduring colonial cultural aggression has been rendered invisible and legitimated by state governments and upheld by majority Settler populations. Colonialism is not a thing of the past, colonialism continues to be expressed in new and pervasive ways, such as extractive imperialism through the displacement of Indigenous peoples and the global extraction of resources from their traditional territories. Extractivism exerts ongoing pressure upon Indigenous 
worldviews and cultural practices (Caxaj, Berman, Varcoe, Ray, \& Restoulec, 2014) contributing to collective and cumulative experiences of colonial trauma and related health disparities.

\section{The Complex, Continuous, Collective, Cumulative and Compounding Experience of Colonial Trauma}

The colonial trauma endured by Indigenous peoples can be described as complex, continuous, collective, and cumulative with the resulting transmission of compounded trauma across generations (Mitchell, 2016).

Complex.

The colonial trauma inflicted upon Indigenous peoples has a complex and profoundly harmful nature. The complex trauma affects individual at the emotional, spiritual, intellectual, physical, and social domains with impacts at all levels of Indigenous communities, not only the individual but also the family unit, the community collective, and the Nation. A comprehensive complex of interacting trauma has been inflicted for centuries on Indigenous peoples on many levels of the individual person and all levels of the collective. Indigenous communities with the exception of a number of thriving Indigenous nations in Canada and elsewhere are faced with disproportionately high levels of substance abuse, health inequalities, suicide, and violence which have been linked to cultural discontinuity and oppression (Kirmayer, Brass, \& Tait, 2000; Mitchell \& MacLeod, 2014; Mitchell \& Maracle, 2005). This social reality cannot be fully understood without addressing the colonial contexts which have impacted, and continue to impact, the lives of Indigenous peoples (de Leeuw, Greenwood, \& Cameron, 2010).

\section{Continuous.}

Colonial assaults have been inflicted on Indigenous peoples for more than 500 years with the trauma being carried forward from the past experiences of ancestors and near relatives and transmitted forward to children and future generations intergenerationally. In the early 19th and middle 20th century epidemics of smallpox, influenza, and measles resulted in millions of deaths due to the lack of immunity to European diseases followed by starvation and war. The decimation of the First Nation population in Canada from 2 million to 150,000 was followed by racist government policies, the illegalization of spiritual practices, as well as cultural suppression and violation through forced relocation, the implementation of assimilation policies of involuntary enfranchisement (the gaining of citizen status at the cost of Indigenous identity under the law), residential schooling, and interference in local governance. 


\section{Collective.}

The colonial trauma endured by Indigenous peoples is by its very nature collective. It is a comprehensive and relentless assault on the spiritual, emotional, intellectual, and socio-ecological nature of Indigenous peoples and their cultures (Duran, 2006). Collective trauma is described by Abadian (1996) as trauma communities suffer when powerful forces violate their physical and/or sociocultural integrity.

\section{Cumulative.}

When healing from colonial trauma has not taken place, when there has been little opportunity for adequate grieving, healing, and reconciliation the trauma may be passed on from generation to generation. This has in turn resulted in what has been termed intergenerational trauma; trauma that is experienced indirectly across multiple generations and between generations. Intergenerational trauma is compounded and extended by the direct transmission of further trauma, what has been termed lateral or horizontal violence, as the impact of cultural dislocation and internalized oppression is manifested in internal conflict (Duran, Duran, Brave Heart \& Yellow Horse, 1998). Residential schooling and its longterm effects on families and communities is an example of the cumulative and compounding impact of colonial trauma. Residential schools were undoubtedly one of the most pernicious and powerful practices of cultural genocide; through the removal of children from their cultures, their communities and their families. The impact of this personal, family and community level trauma has proven to be cumulative "becoming more severe as it is passed onto subsequent generations" (Duran, 2006, p 16). No other cultural groups have endured the long term removal of its children followed by the cataclysmic impact on a culture of adult parents who have grown up in severe institutional industrial school settings, designed to "kill the Indian in the child" (Indian and Northern Affairs Canada, 2008). The systematic and institutionalized removal of Indigenous children away from the love, protection, and socialization of their families and communities appears historically unique, beyond other examples of ethnocide, illustrating the contemporary brutality of racism with the deliberate intent to destroy cultures and communities.

\section{Compounding.}

The Royal Commission on Aboriginal Peoples (1996) provides important and compelling documentation of the impact of the compound colonial trauma endured by the First Peoples of Canada. The assimilative policy of residential schooling was a calculated wave of colonial assault that was stacked upon the traumatic burden of hundreds of years of disease, land appropriation, starvation, and the banning of cultural and religious practices imposed upon Indigenous peoples. 
Decade after decade, century after century, Indigenous peoples have, however, resisted colonial aggression and colonial interference. While there has been remarkable resistance and survival worldwide, five hundred years of colonial trauma legitimized and enforced by the dominant cultures has left its impact. Colonial trauma has affected multiple generations in complex, continuous, collective, cumulative and compounded ways. A 2016 Australian review of the literature found "a general consensus that the impact of colonisation on the health of Indigenous people is highly complex and that the legacies are experienced intra-generationally and inter-generationally" (Griffiths, Coleman, Lee, \& Madden, 2016, p. 9).

Central to the ongoing, collective and cumulative impacts of colonialism is the failure of Sates to recognize Indigenous Peoples' right to self-determination. Strongly linked to the mental and physical health of Indigenous peoples is the right to self-determination which is a fundamental principle of human rights law embodied in the Charter of the United Nations (1945), the International Covenant on Civil and Political Rights (OHCHR, 1966b) and the International Covenant on Economic, Social and Cultural Rights (OHCHR, 1966a). Common Article 1, paragraph 1 of these Covenants provides that: "All peoples have the rights of self-determination. By virtue of that right they freely determine their political status and freely pursue their economic, social and cultural development." The right to selfdetermination is further embedded in Article 3 of the United Nations Declaration on the Rights of Indigenous Peoples.

The principle of self-determination, a right of all people, is further embodied in Article 3 of the United Nations Declaration on the Rights of Indigenous Peoples. Indigenous peoples, have, however, not fully enjoyed the basic human right of self-determination as embodied in international law (Dessanti, 2015) or the United Nations Declaration on the Rights of Indigenous Peoples.

Colonial trauma has disrupted Indigenous identity contributing to the current situations of poor health because Indigenous people have been intruded upon, and removed from their collectivities and territories. This is evident within Indigenous reserve communities in Canada today. Within Indigenous communities, individuals may live as a group of Indigenous people that live in the same location while separated from their cultural traditions. This has resulted in a reduction in the fulfilling of ancestral roles, duties and responsibilities that are essential to the sustainability and wellbeing of Indigeneity and Indigenous collectivities. The assimilation policies have created Indigenous individuals, with profound disruption to the sense of belonging to a collective Nation, as evident in current levels of lateral violence. 


\section{Trauma Informed Indigenous Health Policy and Services}

The International Covenant on Economic, Social and Cultural Rights (OHCHR,1966a), widely considered as the central instrument of protection for the right to health, recognizes "the right of everyone to the enjoyment of the highest attainable standard of physical and mental health" (art. 12, para. 1). The World Health Organization maintains that most health disparities are avoidable and that health disparities representing significant inequalities are unacceptable. If colonial trauma, as argued here, is a key political determinant of health that serves as an explanatory factor for the health inequities borne by Indigenous peoples, colonialism itself needs to be addressed and taken up within society as a whole and addressed within mental health services. Failure to identify the ongoing traumagenic force of contemporary forms of colonialism perpetuates the pathologizing of Indigenous peoples and communities (Maxwell, 2014) while failing to address the sickness of colonialism that inflicts "heinous wounds on the Indigenous population that they [colonizers] set out to civilize" (Henderson \& Wakeham, 2009, p. 11).

The social determinants of health need to be significantly modified to include political dimensions such as government policies, environmental legislation, and extractivism all of which are critical to protecting and improving the health status of Indigenous populations.

It is important, moving forward, for research on the mental health of Indigenous peoples to consider the concept of colonialism carefully, in order to ensure that the societal and structural level problems of a colonial society are not obscured by attention to the immediate mental health needs of individuals. Both can be considered simultaneously. (Nelson \& Wilson, 2017, p. 100).

The advancement of Indigenous peoples' health and well-being must be grounded in an understanding of both the political and historical context of colonial trauma in order to understand the complexity and extensiveness of contemporary colonial traumagenic forces and related health impacts. There is an urgent need for health researchers and policymakers to work in collaboration with Indigenous peoples to contribute to health policies and services that promote powerful solutions for restoring and rebuilding Indigenous identity, that will in turn support the restoration and renewal of Indigenous collectivities.

Shifting the focus and dialogue on Indigenous mental health from the individual to the collective, and from the personal to the political, calls for the development of political pathways to healing [...] Issues of systemic racism, policies of assimilation, ongoing land and resource struggles, cultural genocide and colonial 
trauma are rarely identified within the dominant culture as explanatory factors in relation to the contemporary Indigenous health crisis. (Mitchell, 2016, p.145)

\section{Conclusion}

The social and health inequalities borne by Indigenous peoples were identified as a gross social injustice in the context of the explanatory theory of colonial trauma. Acknowledging and addressing both historical and contemporary forms of colonialism and traumagenic impacts is a critical mental health strategy to advance the health and human rights of Indigenous peoples. A commitment to culturally appropriate, just, and effective health policies and services informed by the concept of colonial trauma developed in collaboration with affected populations is proposed.

Strongly linked to the mental and physical health of Indigenous peoples is the right to selfdetermination which is a fundamental principle of human rights law embodied in the Charter of the United Nations, international law and the United Nations Declaration on the Rights of Indigenous Peoples. There is a need to extend the determinants of health framework and the examination of community well-being to include both social and political determinants (Canada, 2018) which advance the right to self-determination. The recognition of the political and cultural dimension of selfdetermination informs the collective nature of Indigenous health and wellness and considers Indigenous perspectives on and experiences of mental health and wellbeing.

We presented colonial trauma as a verb that identifies the traumagenic nature of colonial policies and practices, including cultural interference and ongoing policies and practices of assimilation that violate the right to self-determination. We presented the theory of colonial trauma as an explanatory framework for the gross health disparities suffered by Indigenous peoples globally, with Canada as a wealthy democratic country as an illustrative example.

The theory of colonial trauma is recommended as a conceptual framework from which to research, screen, monitor, diagnose and treat the presentation of complex, continuous, collective, cumulative, and compounding forms of colonial trauma in health care research, policy, and clinical practice within Canada and as an essential foundation for beginning pathways to reconciliation. 


\section{References}

Abadian, S. (1999) From wasteland to homeland: Trauma and the renewal of Indigenous peoples and their communities. Unpublished Dissertation, Ann Arbor, MI: University of Michigan.

Aboriginal Affairs and Northern Development Canada. (2015). The community well-being index: Wellbeing in First Nations communities, 1981-2011. Ottawa: Her Majesty the Queen in Right of Canada, represented by the Minister of Aboriginal Affairs and Northern Development.

Adams, H. (1989). Prison of grass. Saskatoon, SK, Canada: Fifth House Publishers. American Psychiatric Association. (2000). Diagnostic and statistical manual of mental disorders. (4th ed., text rev.). Washington, DC: American Psychiatric Association.

Anaya, J. (2011, December 20). Canada/Attawapiskat First Nation: Statement by the UN Special Rapporteur on Indigenous peoples. United Nations Human Rights Office of the High Commissioner.

Anaya, J. (2014). Report of the Special Rapporteur on the rights of Indigenous peoples, James Anaya: The situation of Indigenous peoples in Canada. United Nations General Assembly (A/HRC/27/52/Add.2).

Arquette, M., Cole, M., Cook, K., LaFrance, B., Peters, M., Ransom, J., Sargent, E., Smoke, V., \& Stairs, A. (2002). Holistic risk-based environmental decision making: A native perspective. Environmental Health Perspectives, 110, 259-264.

Armstrong, J. C. , \& Grauer, L. (Eds). (2001). Native Poetry in Canada: A Comparative

Anthology. Peterborough, Ont.; Orchard Park, NY: Broadview Press.

Berger, T. R. (1991). A long and terrible shadow: White values, Native rights in the Americas, 14921992. Vancouver: Douglas \& McIntyre Ltd.

Brave Heart, M.Y.H., \& DeBruyn, L. M. (1998). The American Indian holocaust: Healing historical unresolved grief. American Indian and Alaska Native Mental Health Research, 8, 60-82.

Brave Heart, M.Y.H. (1999). Oyate Ptayela: Rebuilding the Lakota nation through addressing historical trauma among Lakota parents. Journal of Human Behavior in the Social Environment, 2, 109-126.

Brave Heart, M.Y.H. (2000). Wakiksuyapi: Carrying the historical trauma of the Lakota. Tulane Studies in Social Welfare, 21-22, 245-266.

Brave Heart, M.Y.H. (2003) The historical trauma response among Natives and its relationship with substance abuse: A Lakota illustration. Journal of Psychoactive Drugs, 35, 7-13. 
Brave Heart, M., Chase, J., Elkins, J., \& Altschul, D.B. (2011). Historical trauma among Indigenous peoples of the Americas: Concepts, research, and clinical considerations. Journal of Psychoactive Drugs, 43, 282-290.

Cardinal, H. (1969). The unjust society. Edmonton: Hurtig Publishers.

Canada. (2018). Report 5 - of the Auditor General of Canada to the House of Commons Socioeconomic Gaps on First Nations Reserves- Indigenous Services Canada. Ottawa: Office of the Auditor General of Canada. http://www.oagbvg.gc.ca/internet/English/parl_oag_201805_05_e_43037.html

Caxaj, S. C., Berman, H., Varcoe, C., Ray, S. L., \& Restoulec, J-P. (2014). Gold mining on Mayan-Mam territory: Social unravelling, discord and distress in the western highlands of Guatemala. Social Science \& Medicine, 111, 50-57.

Charter of the United Nations. (1945). United Nations. Retrieved from: http://www.un.org/en/charterunited-nations/

Chief Dan George. (1967). Speech given at Canada's centennial celebration in Vancouver, British Columbia by hereditary Chief of the Coast Salish tribe and honorary Chief of the Squamish tribe of British Columbia, Canada.

Choudry, A. (2010). What's left? Canada's 'global justice' movement and colonial amnesia. Race \& Class, 52, 97-102.

Cohen, A. (1999). The mental health of Indigenous peoples: An international overview. A report prepared for the Department of Mental Health (WHO/MNH/NAM/99.1). Geneva: World Health Organization.

Crawford, A. (2014). "The trauma experienced by generations past having an effect in their descendants": Narrative and historical trauma among Inuit in Nunavut, Canada. Transcultural Psychiatry, 51, 339-369.

de Leeuw, S., Greenwood, M., \& Cameron, E. (2010). Deviant constructions: How governments preserve colonial narratives of addictions and poor mental health to intervene into the lives of Indigenous children and families in Canada. International Journal of Mental Health \& Addiction, 8, 282-295.

Doyle, K. (2012). Measuring cultural appropriateness of mental health services for Australian Aboriginal peoples in rural and remote Western Australia: A client/clinician's journey. International Journal of Culture and Mental Health, 5, 40-53.

Duran, E. (2006). Healing the soul wound: Counseling with American Indians and other Native peoples. New York, NY: Teachers College Press. 
Duran, E., Duran, B., Brave Heart, M.Y.H., \& Yellow Horse, S.D. (1998). Healing the American Indian soul wound. In Danieli, Y. (Ed.), International handbook of multigenerational legacies of trauma (pp. 341-354). NY: Plenum Press.

Duran, E. \& Duran, B. (1995). Native American post-colonial psychology. Albany: State University of New York Press.

Evans-Campbell, T. (2008). Historical trauma in American Indian/Native Alaska communities: A multilevel framework for exploring impacts on individuals, families, and communities. Journal of Interpersonal Violence, 23, 316-338.

Fry, B. \& Mitchell, T. (2016). Towards coexistence: Exploring the differences between Indigenous and non-Indigenous perspectives on land. Native Studies Review, 23, 35-64.

Funston, L. (2013). Aboriginal and Torres Strait Islander worldviews and cultural safety transforming sexual assault service provision for children and young people. International Journal of Environmental Research and Public Health, 10, 3818-3833.

Griffiths, K., Coleman, C., Lee, V., \& Madden, R., (2016). How colonisation determines social justice and Indigenous health: A review of the literature. J Pop Research, 33, 9-30.

Henderson, J. \& Wakeham, P. (2009). Colonial reckoning, national reconciliation? Aboriginal peoples and the culture of redress in Canada. ESC, 35, 1-26.

Indian and Northern Affairs Canada. (2008, June). Statement of apology by Prime Minister Harper to former students of Indian Residential Schools. Ottawa, ON, CA.

Kirmayer, L. J., Brass, G. M., \& Tait, C. L. (2000). The mental health of Aboriginal peoples: Transformations of identity and community. Canadian Journal of Psychiatry, 45, 607616.

Kirmayer, L. J., Gone, J. P., \& Moses, J. (2014). Rethinking historical trauma. Transcultural Psychiatry, 51, 299-319.

Kirmayer, L. J. \& Valaskakis, G. G. (2009). Healing traditions: The mental health of Aboriginal peoples in Canada. UBC Press.

Kral, M. J., Idlout, L., Minore, J. B., Dyck, R. J., \& Kirmayer, L. J. (2011). Unikkaartuit: Meanings of well-being, unhappiness, health, and community change among Inuit in Nunavut, Canada. American Journal of Community Psychology, 48, 426-438.

Krieg, A. (2009). The experience of collective trauma in Australian Indigenous communities. Australasian Psychiatry, 17, S28-S32. 
Laduke, W. (1999). All our relations: Native struggles for land and life. Cambridge, MA: South End Press.

Lambert, C. (2008). Trails of tears and hope. Harvard Magazine, 11, no 4.

Loppie Reading, C. \& Wien, F. (2009). Health inequities and social determinants of Aboriginal peoples' health. National Collaborating Centre for Aboriginal Health.

Lloyd, D. (2000). Colonial trauma/postcolonial recovery? Interventions, 2, 212-228.

Manson, S., Beals, J., O'Nell, T., Piasecki, J., Bechtold, D., Keane, E., et al (Eds.). (1996). Wounded spirits, ailing hearts: PTSD and related disorders among American Indians. Washington, DC, US: American Psychological Association.

Marrone, S. (2007). Understanding barriers to health care: A review of disparities in health care services among Indigenous populations. International Journal of Circumpolar Health, 66, 188-198.

Maxim, P. S., White, J. E., Beavon, D., \& Whitehead, P. C. (2001). Dispersion and polarization of income among Aboriginal and non-Aboriginal Canadians. Canadian Review of Sociology/Revue Canadienne de Sociologie, 38, 465-476.

Maxwell, K. (2014). Historicizing historical trauma theory: Troubling the trans-generational transmission paradigm. Transcultural Psychiatry, 51, 407-435.

McCabe, G. H. (2007). The healing path: A culture and community-derived Indigenous therapy model. Psychotherapy: Theory, Research, Practice, Training, 44, 148-160.

McClintock, A. (1992). The angel of progress: Pitfalls of the term "post-colonialism". Social Text, 31/32, 84-98.

Miller, J. R. (1991). Skyscrapers hide the heavens: A history of Indian-White relations in Canada. Toronto: University of Toronto Press.

Miller, J. R. (2004). Lethal legacy: Current Native controversies in Canada. Toronto, Canada: McClelland \& Stewart Ltd.

Mitchell, T.L. (1993). Old wounds, new beginnings: Challenging the missionary paradigm in NativeWhite relations: A cross-cultural perspective on sexual abuse service development in a Yukon community. Ph.D. Dissertation, University of Toronto.

Mitchell, T. (2016). Colonial trauma and political pathways to healing. In S. L. Stewart, R. Moodley, \& A. Hyatt (Eds.) Indigenous cultures and mental health counselling: Four directions for integration with counselling psychology (pp. 141-154). New York: Routledge Press. 
Mitchell, T. (2014). International gaze brings critical focus to questions about Indigenous rights and governance in Canada. In T. Mitchell (Ed.) The Internationalization of Indigenous Rights: UNDRIP in the Canadian Context (pp. 43-47). CIGI Special Report. Waterloo, ON: Centre for International Governance Innovation.

Mitchell, T. \& McLeod, T. (2014). Aboriginal Social Policy: A critical community mental health issue. Canadian Journal of Community Mental Health. 33(1), 109-122.

Mitchell, T. L. \& Maracle, D.T. (2005). Healing the generations: Post-traumatic stress and the health status of Aboriginal populations in Canada. Journal of Aboriginal Health, 2, 1424.

Morrissette, P. J. (1994). The holocaust of First Nation people: Residual effects on parenting and treatment implications. Contemporary Family Therapy, 16, 381-392.

Nelson, S. E. \& Wilson, K. (2017). The mental health of Indigenous peoples in Canada: A critical review of research. Social Science and Medicine, 176, 93-112.

Office of the United Nations High Commissioner for Human Rights (OHCHR). (1966a). International covenant on economic, social and cultural rights. Retrieved from http://www.ohchr.org/EN/ProfessionalInterest/Pages/CESCR.aspx

Office of the United Nations High Commissioner for Human Rights (OHCHR). (1966b). International covenant on civil and political rights. Retrieved from https://www.ohchr.org/en/professionalinterest/pages/ccpr.aspx

Paradies, Y. (2016). Colonisation, racism and indigenous health. J Pop Research, 33, 83-96.

Prime Minister Harper (2008). (https:/www.cbc.ca/news/canada/prime-minister-stephen-harper-sstatement-of-apology-1.734250)

Prussing, E. (2014). Historical trauma: Politics of a conceptual framework. Transcultural Psychiatry, 51, 436-458.

Royal Commission on Aboriginal Peoples (RCAP). (1996). Report of the Royal Commission on Aboriginal Peoples. Ottawa: Royal Commission on Aboriginal Peoples.

Saul, J. R. (2008). A fair country: Telling truths about Canada. Toronto: Viking Canada, Penguin Group.

Shewell, H \& Spagnut, A. (1995). The First Nations of Canada: Social welfare and the quest for self government. In J. E. Dixon \& R. P. Scheurell (Eds.). Social welfare and Indigenous peoples. New York: Routledge.

Sherwood, J. (2009). Who is not coping with colonization? Laying out the map for decolonization. Australasian Psychiatry, 17, S24-S27. 
Simpson, L. (2004). Anticolonial strategies for the recovery and maintenance of Indigenous knowledge. American Indian Quarterly, 28, 373-384.

Smylie, J. \& Firestone, M. (2016). The health of Indigenous peoples. In D. Raphael (Ed). Social Determinants of Health: Canadian Perspectives, (pp.434-469). 3rd ed. Toronto, Canadian Scholars' Press.

Stannard, D. E. (1992). American Holocaust: Columbus and the conquest of the New World. New York: Oxford University Press.

Stewart, S., Riecken, T., Scott, T., Tanaka, M., \& Riecken, J. (2008). Expanding health literacy: Indigenous youth creating videos. Journal of Health Psychology, 13, 180-190.

Sweet, M. A., Dudgeon, P., McCallum, K., \& Ricketson, M. D. (2014). Decolonizing practices: Can journalism learn from health care to improve Indigenous health outcomes? The Medical Journal of Australia, 200, 626-627.

Taylor, A. (2007). The divided ground: Indians, Settlers, and the Northern borderland of American Revolution. Toronto, ON, Random House, Vintage Press.

Thomas, D., Mitchell, T., \& Arseneau, C. (2016). Re-evaluating "resilience": From individual vulnerabilities to strengths of cultures and collectivities among Indigenous communities. Resilience: International policies, practices and discourses, 4, 116-129.

Thompson, J. (2008). Apology, justice and respect: A critical defense of political apology. In M. Gibney \& R. E. Howard-Hassmann (Eds.) The age of apology: Facing up to the past (pp. 31-44). Philadelphia: University of Pennsylvania Press.

Titley, E. B. (1992). A narrow vision: Duncan Campbell Scott on the Administration of Indian Affairs in Canada. Vancouver, Canada: University of British Columbia Press.

United Nations. (2009). State of the world's Indigenous peoples. New York: Department of Economic and Social Affairs, Division for Social Policy and Development, Secretariat of the Permanent Forum on Indigenous Issues.

Waldram, J. B. (1997). The way of the pipe: Aboriginal spirituality and symbolic healing in Canadian prisons. Peterborough, ON: Broadview Press.

Waldram, J. B., Herring, D. A., \& Young, T. K. (2006). Aboriginal health in Canada: Historical, cultural, and epidemiological perspectives (2nd ed.). Toronto, Canada: University of Toronto Press. 
Walters, K.L., Mohammed, S.A., Evans-Campbell, T., Beltran, R.E., Chase, D.H., \& Duran, B. (2011). Bodies don't just tell stories, they tell histories: Embodiment of historical trauma among American Indians and Alaska Natives. Social Science Research on Race, 8, 179189.

Whitbeck, L. B., Adams, G. W., Hoyt, D. R., Chen, X. (2004). Conceptualizing and measuring historical trauma among American Indian people. American Journal of Community Psychology, 33, 119130.

World Health Organization. (2007). Indigenous peoples' health: Health and human rights. Health and Human Rights Team, Department of Ethics, Equity, Trade \& Human Rights. Geneva: World Health Organization.

York, G. (1990). The dispossessed: Life and death in Native Canada. London, United Kingdom, Random House.

Young, T. K. (2003). Review of research on aboriginal populations in Canada: Relevance to their health needs. British Medical Journal, 327, 419-422. 